\title{
Genetic Diversity in Kenyan Populations of Acacia senegal (L.) Willd. Based on ISSR Markers
}

\author{
By C. J. Chiveu ${ }^{\left.1),{ }^{*}\right)}$, O. G. Dangasur ${ }^{2)}$, M. E. Omunyin ${ }^{1)}$ and F. N. Wachira ${ }^{3)}$
}

(Received $24^{\text {th }}$ October 2007)

\begin{abstract}
Acacia senegal (L.) Willd is an African arid and semi arid zones, leguminous multipurpose tree species belonging to the subfamily Mimosoideae, family Fabaceae and subgenus Aculeiferum, highly valued for gum arabic production. Patterns of genetic diversity of this important species in Kenya have not been studied for efficiency of germplasm utilization, conservation and improvement. Four natural populations of $A$. senegal in Kenya (Bulla Sambul, Kutulo, Wamba and Meisori) were analyzed to estimate genetic variation among and within populations, by use of ISSR (Inter-simple sequence repeat) markers. Using five primers, 17 polymorphic loci were observed, ranging in size from 564bp to $983 \mathrm{bp}$. A high mean total genetic diversity index for the species was observed $(H=0.27)$. The principal coordinates analysis (PCoA) of the 95 samples from the four populations showed that about $40.75 \%$ of the total variation was described by the first two axes with much overlap among populations; hence populations were not defined on the basis of geographic distance. Much of the genetic variation resided within the populations based on the coefficient of gene differentiation $(G s t=0.0573)$ and Analysis of Molecular Variance (AMOVA) (95\%). It was therefore recommended that selection for the desired important economic traits for improvement and conservation should emphasize on individual trees within populations rather than among populations, and also ensure a comprehensive coverage of the entire ecological amplitude of the populations.
\end{abstract}

Key words: Acacia senegal, genetic diversity, ISSR, multipurpose, Kenya, differentiation, population, geographical structuring, selection, conservation.

\section{Introduction}

Acacia senegal (L.) Willd is a leguminous multipurpose African tree species belonging to subfamily Mimosoideae, family Fabaceae. It is a deciduous shrub or tree which grows to $2-15 \mathrm{~m}$ tall with a flat or rounded crown (MAUNDU et al., 1999). Based chiefly on characters of the seed and seedlings, absence of stipular spines (but prickles present) and pollen characters, the species has been classified in the subgenus Aculeiferum (ARCE and BANKS, 2001).

\footnotetext{
1) Department of Seed, Crop and Horticultural Sciences, Moi University, P.O. Box 1125, Eldoret, Kenya. Telephone: +254721421430. E-Mail: chiveuj@yahoo.com

2) Department of Biological Sciences, Moi University, P.O. Box 1125, Eldoret, Kenya Telephone: +254-722689574. E-Mail: georgedangasuk@yahoo.com

3) Department of Biochemistry and Molecular Biology, Egerton University, P.O. Box 536, Njoro, Kenya. Telephone: +254722644279. E-Mail: fwachira@yahoo.com

*) Corresponding author: Chemulanga Josiah Chiveu.
}

A. senegal is highly valued for centuries for gum arabic production, which is used in food, pharmaceuticals and other industries in USA and Europe (ICRAF, 1992). Gum arabic is approved for use as food additives by the US Food and Drug Administration and is on the list of substances that are generally recognized as safe (DondAin and PhILlips, 1999). Other uses include soil fertility restoration by way of atmospheric nitrogen fixation, provision of wood for fuel, local construction and poles for fence posts. Fiber from the root bark is used to make ropes and fish nets (NAS, 1984). In addition, the species seeds are used as vegetables by humans while pods and leaves provide fodder for livestock (FAO and UnEP, 1983). The species is also used in agroforestry systems and in desertification control through sand dune stabilization and as wind breaks (CossALTER, 1991).

Acacia senegal extends over a wide ecological range. It is widespread in tropical and sub tropical Africa. The zone in which the $A$. senegal tree grows is known as the gum arabic belt, with the altitude ranging between 100 1950 meters above sea level (masl) (MAUNDU et al., 1999). The species is drought resistant growing on sites with annual rainfall of 100-950 mm, but mainly between 300-400 $\mathrm{mm}$ and 5-11 months of dry periods. It tolerates temperatures of up to $45^{\circ} \mathrm{C}$ or more, dry winds and sand storms (MAUNDU et al., 1999). The tree species is adapted to dry tropics and performs well on poor soils (BOER, 2002).

In Kenya, the A. senegal tree grows on Homa hill in the rift valley, Lokitaung and Mutha hill in dry Acacia commiphora bush land in dry areas. High densities and sometimes pure stands of this species have been found in parts of Turkana and Baringo districts. The tree is also spread in Samburu district and North Eastern Province in Garissa and Wajir districts (MAUNDU et al., 1999). There is currently a great interest among Kenyan farmers to grow $A$. senegal on a commercial basis due to its many uses and particularly for gum arabic production for export. Therefore, in order to make Acacia senegal farming in Kenya a commercially viable enterprise, there is urgent need to conduct genetic diversity assessment of the species throughout its natural habitats in the country.

The diversity of environmental conditions, especially moisture, under which $A$. senegal occurs naturally suggest that there is a great genetic variability among the populations of the species (BRENAN, 1983). FAGG and AlLison (2004) reported variation in gum chemical composition, molecular as well as morphological characteristics between Ugandan and Sudanese populations of A. senegal. Differences in gum chemical composition 


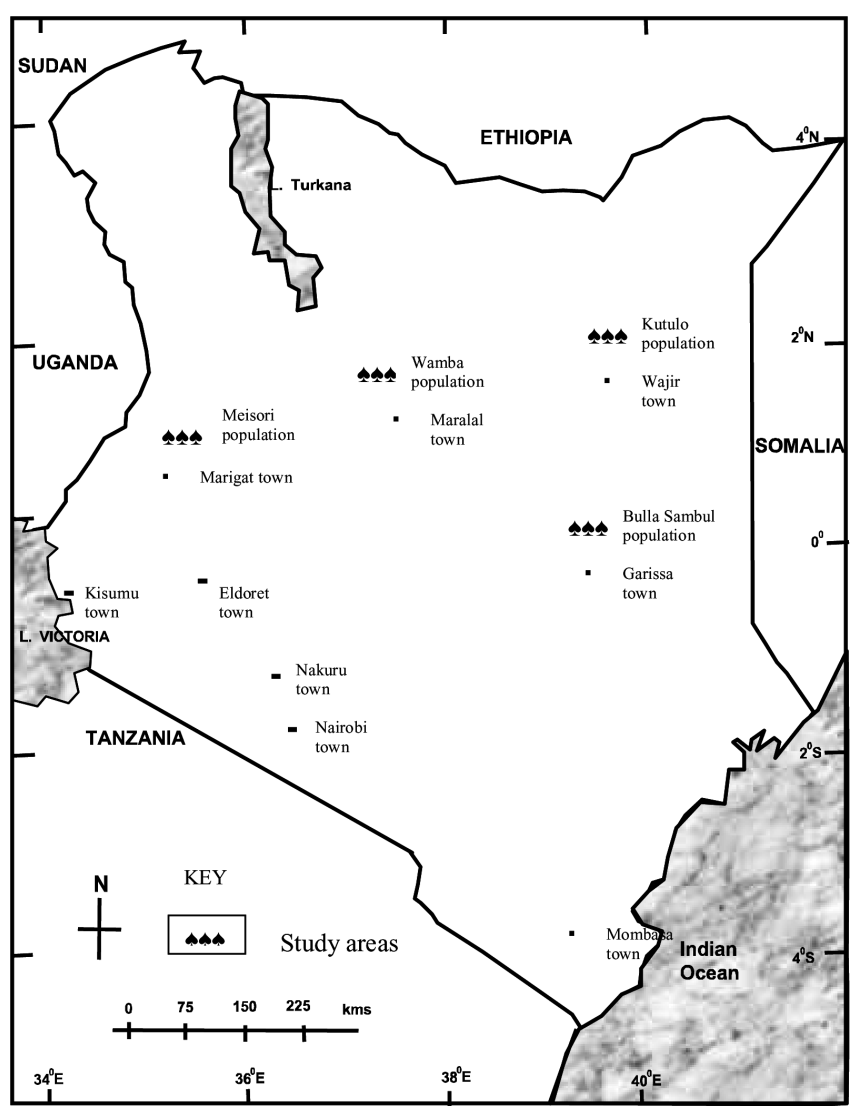

Figure 1. - Locations of study areas for genetic diversity of A. senegal in Kenya situated in four districts of Kenya.

based on sources of origin has also been reported within Kenyan populations of the species (CHIKAMAI and ODERA, 2002). The understanding of the genetic variation under these varying environmental conditions is therefore imperative for development of any strategy for germplasm collection, management and conservation, domestication and improvement of the species' genetic resources (OlEGHE and AKINOUFESI, 1992).

Molecular and biochemical techniques provide a powerful set of tools for the study of plant population genetics (BARDAKCI, 2001). The study of genetic diversity of A. senegal using isozymes in the West African provenances revealed little variation (BOER, 2002). However, in most plants, isozyme variation is limited by both the numbers of polymorphic enzyme systems and loci that can be analyzed. Data from RAPD studies in plant species usually showed similar or greater diversity than from allozymes (EssELMAN et al., 1999, 2000). The former often prove more variable than the latter. For example, no allozyme variation was found in some species of Dendroseris although RAPD diversity was detected (ESSELMAN et al., 2000). ISSR is a RAPD-like technique that shares the simplicity of RAPD markers but uses longer PCR primers; hence, it is more reproducible than the original RAPD method. The primers may also be anchored at the 5' or 3' end with a few nucleotides to increase specificity of priming. Because of greater length of ISSR primers, they may show greater repeatability and stability of map position in the genome when comparing genotypes of closely related individuals (ZIETKIEWICZ et al., 1994). The technique generates larger numbers of polymorphisms per primer because variable regions in the genome are targeted (HANTula et al., 1996; MondAL, 2002). Accordingly, ISSRs have been widely used to detect polymorphisms, analyze phylogenetic relationships and evaluate the variation within and among landrace mixtures (WOLFE and LisTON, 1998; CAMACHO and ListON, 2001; NAN et al., 2003). However, the use of ISSR markers for research on $A$. senegal population genetic diversity has not been reported in Kenya.

In this paper, we estimated the genetic diversity of four populations of $A$. senegal in Kenya using ISSR technique to provide a guide for effective management and selection of economically important traits for domestication and improvement of this multipurpose African tree species.

\section{Materials and Methods}

\section{Plant material}

Sample collection was carried out in four districts of Kenya: Wajir district (Kutulo population), Garissa district (Bulla Sambul population), Samburu district (Wamba population) and Baringo district (Meisori population) (Figure 1 and Table 1), representing the major regions where the species is found in Kenya and utilized effectively for agroforestry and gum trade.

Systematic sampling design was employed where a distance of 300-500 m was established along an imaginary path created for the purpose of the research across the population. The path acted as a line transect from one sampling point to the other within a population. A distance of 50-100 m left and right of the path into the tree stand was then established. The tree which was near to the established distance was selected for sample collection. This was purposely done to avoid sampling closely related individuals. Two trees were sampled at every sampling point, one from each side of the path. In total, the samples represented four populations, 19 samples from each of the Bulla Sambul, Kutulo and Wamba populations, and 38 samples from the Meisori population. Young healthy leaf samples were picked from every sampled tree for eventual DNA analysis in the laboratory. In total, 95 samples were analyzed for molecular work.

Table 1. - Collection site data of A. senegal in Kenya used in this study.

\begin{tabular}{lllllll}
\hline District & Population & Latitude & Longitude & $\begin{array}{l}\text { Altitude } \\
(\mathrm{m})\end{array}$ & $\begin{array}{l}\text { Mean annual } \\
\text { rainfall }(\mathrm{mm})\end{array}$ & $\begin{array}{l}\text { Mean annual } \\
\text { Temperature }\left({ }^{\circ} \mathrm{C}\right)\end{array}$ \\
\hline Garissa & Bulla Sambul & $0^{\circ} 27^{\prime} 25^{\prime} \mathrm{S}$ & $39^{\circ} 39^{\prime} 30^{\prime} \mathrm{E}$ & 235 & 350 & 29.5 \\
Wajir & Kutulo & $1^{\circ} 44^{\prime} 05^{\prime} \mathrm{N}$ & $40^{\circ} 04^{\prime} 08^{\prime} \mathrm{E}$ & 205 & 320 & 28 \\
Samburu & Wamba & $0^{\circ} 40^{\prime} 31^{\prime} \mathrm{N}$ & $36^{\circ} 02^{\prime} 10^{\prime} \mathrm{E}$ & 975 & 475 & 26.5 \\
Baringo & Meisori & $0^{\circ} 28^{\prime} 00^{\prime} \mathrm{N}$ & $36^{\circ} 00^{\prime} 00^{\prime} \mathrm{E}$ & 1000 & 650 & 24 \\
\hline
\end{tabular}




\section{Total DNA extraction}

DNA was isolated from $0.5 \mathrm{~g}$ of the fresh leaf material using the modification of the CTAB method of FAO/IAEA (2002) as follows: Approximately 0.5g of the leaf samples was weighed into the $1.5 \mathrm{ml}$ microcentrifuge tube and the tube put into liquid nitrogen. Grinding was then done quickly but carefully to a fine powder by use of grinding rods, not allowing the tissue to thaw. About 100 $\mathrm{mg}$ of polyvinylpolypyrrollidone (PVPP) was added to the leaf powder to remove polyphenolic compounds. Six hundred microlitres $(600 \mu \mathrm{l})$ of $1.5 \% \mathrm{CTAB}$ extraction buffer (100 mM Tris HCL, pH 7.5; 1.4 mM EDTA, pH $8.0 ; 1.5 \% \mathrm{CTAB}$ ) preheated at $60^{\circ} \mathrm{C}$ in a water bath and then $0.75 \mu \mathrm{l}$ of $\beta$-mercaptoethanol added to it, was then added to the leaf powder. This was then followed by vortexing and the solution incubated with gentle agitation at $60^{\circ} \mathrm{C}$ for 20 minutes in a water bath. The solution was then left to cool down to room temperature, then one volume chloroform: isoamyl alcohol (CIA) (24:1) was added and mixed well to denature the proteins in the suspension. Centrifugation was then done using a Hermle microcentrifuge; model Z-252M at 3,000 rpm for 25 minutes. The upper aqueous phase was then transferred to a fresh $1.5 \mathrm{ml}$ microcentrifuge tube into which $60 \mu \mathrm{l}$ of $10 \% \mathrm{CTAB}$ initially incubated at $65^{\circ} \mathrm{C}$ was added and thoroughly mixed. Six hundred microlitres $(600 \mu \mathrm{l})$ of Chloroform: isoamylalcohol (24:1) was again added and then shaking was done for 20 minutes at room temperature. Centrifugation then followed at 3,000 rpm for 25 minutes. The upper, supernatant phase was then transferred to a fresh, new $1.5 \mathrm{ml}$ microcentrifuge tube into which $2 / 3$-volume isopropanol was added and mixed gently to precipitate the total nucleic acids. After a few minutes, the precipitate DNA was seen suspended in the solution. The precipitate DNA was collected by centrifugation at $5,000 \mathrm{rpm}$ for $20 \mathrm{~min}-$ utes. The liquid was drained carefully and the pellet washed twice with $70 \%$ ethanol by centrifugation at
5,000 rpm for 5 minutes. The ethanol was then drained and the pellet remaining at the bottom of the tube dried on the bench for 3 hours. The pellet was then suspended in $100 \mu \mathrm{NaCl} \mathrm{TE}$ and incubated in a water bath at $55^{\circ} \mathrm{C}$ overnight.

\section{Purification of the extracted DNA}

Purification was also done according to the method of FAO/IAEA (2002) as follows: the RNA which was co-precipitated with DNA was removed by digestion with Ribonuclease A (RNase A) as follows: A stock solution of RNase A (10 mg/ml) was prepared in Tris buffer (Tris$\mathrm{HCl}$, p.H. 7.5; $1 \mathrm{mM} \mathrm{NaCl}$ ), and an aliquot of $2 \mu \mathrm{l}$ added to each DNA sample. The sample was then incubated at $65{ }^{\circ} \mathrm{C}$ for 3 hours to allow for complete digestion of the RNA. Further purification was done by precipitating the DNA by adding $250 \mu \mathrm{l}, 96 \%$ ethanol and left overnight at $-20^{\circ} \mathrm{C}$. The suspended DNA was then centrifuged in a microcentrifuge (Hermle, model Z-252M) at 7,000 rpm for 15 minutes and the liquid drained carefully. The pellet was again washed with $70 \%$ ethanol and centrifuged at 7,000 rpm for 5 minutes and then ethanol was drained and the pellet air-dried on the bench for 3 hours. The pellet was then suspended in $100 \mu \mathrm{l}$ sterile distilled water (SDW) and incubated at $55^{\circ} \mathrm{C}$ overnight.

The DNA quantity and quality (intactness) was visually quantified using the agarose gel electrophoresis method as described by MANNIATIS et al. (1982). Uncut, unmethylated Lambda $(\lambda)$ phage DNA was used as the standard. A working stock of $\lambda$ DNA ( $20 \mathrm{ng} / \mu \mathrm{l})$ was prepared and used for quantification of $A$. senegal DNA extracts. Different concentrations of $\lambda$ DNA (40-200 ng) were electrophoresed with the test DNA samples $(5 \mu \mathrm{l})$, on $1.5 \%$ agarose in $1 \mathrm{X}$ TBE running buffer $(89 \mathrm{mM}$ Tris-HCl, pH 8.0; $89 \mathrm{mM}$ Boric Acid; $2.5 \mathrm{mM}$ EDTA) at a constant voltage of $50 \mathrm{~V}$ for $40 \mathrm{~min}$. After electrophoresis, the gel was stained in ethidium bromide $(0.1 \% \mathrm{w} / \mathrm{v})$ before viewing under ultraviolet light $(312 \mathrm{~nm})$ on a

Table 2. - ISSR oligonucleotide primer sequences screened for genetic diversity of A. senegal in Kenya showing primer code, nucleotide sequence, number of fragments amplified, number of polymorphic fragments and percentage of polymorphic fragments.

\begin{tabular}{clcll}
\hline $\begin{array}{c}\text { Primer } \\
\text { Code }\end{array}$ & $\begin{array}{l}\text { Nucleotide sequence } \\
\left(5^{\prime} \rightarrow 3^{\prime}\right)\end{array}$ & $\begin{array}{l}\text { No. of } \\
\text { fragments } \\
\text { amplified }\end{array}$ & $\begin{array}{l}\text { No. of } \\
\text { polymorphic } \\
\text { fragments }\end{array}$ & $\begin{array}{l}\text { Percentage of } \\
\text { polymorphic } \\
\text { fragments (\%) }\end{array}$ \\
\hline 801 & ATATATATATATATATT & - & - & - \\
804 & TATATATATATATATAA & - & - & - \\
807 & AGAGAGAGAGAGAGAGT & - & - & - \\
842 & GAGAGAGAGAGAGAGATG & - & - & - \\
850 & GTGTGTGTGTGTGTGTTC & - & - & - \\
851 & GTGTGTGTGTGTGTGTCG & - & - & - \\
857 & ACACACACACACACACTG & - & - & - \\
861 & ACCACCACCACCACCACC & - & - & - \\
862 & AGCAGCAGCAGCAGCAGC & - & - & - \\
& & & & 30.0 \\
$808^{*}$ & AGAGAGAGAGAGAGAGAGC & 10 & 3 & 55.6 \\
$810^{*}$ & GAGAGAGAGAGAGAGAT & 9 & 5 & 28.6 \\
$813^{*}$ & CTCTCTCTCTCTCTT & 7 & 2 & 50.0 \\
$817 *$ & CACACACACACACACAA & 8 & 4 & 42.9 \\
$849^{*}$ & TGTGTGTGTGTGTGTTCA & 7 & 3 & 41.4 \\
\hline Mean & & 8.2 & 3.4 & \\
\hline
\end{tabular}

* Primers selected after screening and used for this study. 
transilluminator. The concentrations of the samples were determined by comparing band sizes and staining intensities of the test DNA samples with those of the standard $\lambda$ DNA. The DNA samples were then standardized to concentrations of between 10-30 ng/ $\mathrm{\mu l}$ by appropriate dilutions using sterile distilled water.

A total of 14 ISSR primers (anchored at the 3' end) were screened for polymorphism, reproducibility and their capacity to differentiate among the four populations of A. senegal. Eventually, only five best performing ISSR primers were chosen for use in this study based on the above-mentioned requirements (Table 2).

\section{ISSR PCR amplification}

DNA amplification reactions were performed in a total volume of $10 \mu \mathrm{l}$, each containing $40 \mathrm{ng}$ template genomic DNA; dNTPs (dATP, dCTP, dGTP and dTTP mixture) at $100 \mathrm{nM}$ final concentration; $200 \mathrm{nM}$ oligonucliotide primers (Operon Technologies, USA) anchored at the 3' end; $1 \mathrm{X}$ Taq DNA polymerase buffer, $2.5 \mathrm{mM} \mathrm{MgCl}_{2}$; and 0.5 units of Taq DNA polymerase (Amplitaq Gold, Perkin Elmer, USA). Reactions were set in $0.2 \mathrm{ml} \mathrm{PCR}$ tubes with a mineral oil overlay. Each PCR run included a negative control of sterile distilled water. The amplification was then performed in a thermocycler (Techne PHC-3, UK). The thermocycler was programmed as follows: one cycle of $94^{\circ} \mathrm{C}$ for 5 minutes (Hot start step); 40 cycles of $94^{\circ} \mathrm{C}$ for 30 seconds (denaturation step), $52^{\circ} \mathrm{C}$ for 45 seconds (primer/template annealing step), $72^{\circ} \mathrm{C}$ for 2 minutes (polymerization step); and a final extension phase of 10 minutes at $72^{\circ} \mathrm{C}$ (WILLIAMS et al., 1990). The PCR samples were mixed with $3 \mu$ of gel loading dye (50\% Glycerol, 250 mM EDTA (pH 8.0), 0.01\% Bromophenol blue) and separated by electrophoresis on $1.5 \%$ agarose gels in an electrophoretic tank containing $1 \mathrm{X}$ TBE both as running and gel buffer. The running voltage was 150 volts for three hours. The agarose gels were then stained in Ethidium Bromide $(50 \mu \mathrm{l}$ of $10 \mathrm{mg} / \mathrm{ml}$ solution in 1litre $1 \mathrm{X}$ TBE buffer) for $45 \mathrm{~min}$ utes, and visualized and photographed on a UV transilluminator at $312 \mathrm{~nm}$.

\section{Data analysis}

Only intensely stained unambiguous polymorphic bands were scored for presence (1) and absence (0). Scoring was carried out twice to ensure correct typing. The binary matrix data file created was then configured as an input file for data analysis. NEI's (1973) gene diversity index $(H)$, mean number of alleles per locus $(A)$, percent of polymorphic loci $(P)$, coefficient of gene differentiation $(G s t)$ and genetic distance $(D)$ for each population was derived using POPGENE 3.2 software (YEH et al.,
1999) assuming Hardy-Weinberg equilibrium. PCoA via distance matrix with data standardization for the 95 samples was derived using GenAlEx software (PEAKALL and SMouse, 2006). The data matrix was also subjected to AMOVA to partition the genetic variation within and among the populations using GenAlEx software (PeAKall and Smouse, 2006).

\section{Results}

\section{Genetic variation in A. senegal}

The best 5 ISSR primers produced a total of 17 polymorphic bands with an average of 3.4 polymorphic loci/primer. The product sizes ranged from $564 \mathrm{bp}$ for primers 808 , to $983 \mathrm{bp}$ for primer 813 . The largest number of polymorphic bands was amplified by primer 810 (5 bands), while the least was amplified by primer 813 (2 bands) (Table 2 ).

Table 3 shows the percent polymorphic loci $(P)$, mean observed number of alleles per locus $(A)$ and Nei's genetic diversity index $(H)$. The percent polymorphic loci $(P)$ ranged from $77.8 \%$ for the Wamba population to $94.4 \%$ for the Meisori population. Similarly, the mean observed number of alleles per locus $(A)$ was highest within the Meisori population (1.94) while the Wamba population showed the least variation (1.78), with the Bulla Sambul and Kutulo populations having intermediate values. The mean for observed number of alleles per locus for the populations was 1.86 . The similar pattern was repeated in the gene diversity index $(H)$ which was least in the Wamba population $(H=0.25)$ and highest in the Meisori population $(H=0.30)$. The mean gene diversity index for all the populations was 0.27 .

\section{Genetic differentiation}

The estimated Gst was 0.0573 , indicating that $5.73 \%$ of the total variation existed among the populations while the majority $(94.27 \%)$ of the variation resided within the populations (Table 4). Similarly, the AMOVA performed on the 95 samples for the four populations revealed that $5 \%$ of the variation was apportioned among the populations while $95 \%$ resided within the populations (Table 5). Though both the diversity partitioned components (i.e. between and within populations) were statistically significant, the data suggested that most of the genetic diversity in A. senegal occurs within populations.

The matrix of Nei's unbiased measures of genetic distance (D) (NEI, 1978) is presented in Table 6. Genetic distance ranged from 0.009 between the Meisori and Wamba populations to 0.034 between the Wamba and Bulla Sambul populations with an overall population

Table 3. - The percent polymorphic loci $(P)$, mean observed number of alleles $(A)$ and Nei's gene diversity index $(H)$ among four populations of $A$. senegal.

\begin{tabular}{llll}
\hline Population & $P(\%)$ & $A$ & $H$ \\
\hline Bulla Sambul & 88.9 & 1.89 & 0.27 \\
Kutulo & 88.3 & 1.83 & 0.27 \\
Wamba & 77.8 & 1.78 & 0.25 \\
Meisori & 94.4 & 1.94 & 0.30 \\
\hline Mean & 87.4 & 1.86 & 0.27
\end{tabular}


Table 4. - Estimates of the coefficient of gene differentiation (Gst) across different loci using ISSR primers in the four populations of A. senegal studied.

\begin{tabular}{lcccc}
\hline Locus & Sample Size & $H t$ & $H s$ & Gst \\
\hline $817-1$ & 95 & 0.0000 & 0.0000 & $* * *$ \\
$817-2$ & 95 & 0.2018 & 0.1946 & 0.0356 \\
$817-3$ & 95 & 0.1963 & 0.1873 & 0.0460 \\
$817-4$ & 95 & 0.4067 & 0.4049 & 0.0045 \\
$817-5$ & 95 & 0.3786 & 0.3612 & 0.0459 \\
$849-1$ & 95 & 0.2863 & 0.2855 & 0.0027 \\
$849-2$ & 95 & 0.3983 & 0.3983 & 0.0000 \\
$849-3$ & 95 & 0.2407 & 0.2333 & 0.0308 \\
$808-1$ & 95 & 0.4504 & 0.4252 & 0.0561 \\
$808-2$ & 95 & 0.4269 & 0.3343 & 0.2170 \\
$808-3$ & 95 & 0.2134 & 0.3343 & 0.0354 \\
$813-1$ & 95 & 0.2526 & 0.2487 & 0.0153 \\
$813-2$ & 95 & 0.1420 & 0.1360 & 0.0420 \\
$810-1$ & 95 & 0.4526 & 0.3536 & 0.2186 \\
$810-2$ & 95 & 0.0683 & 0.0608 & 0.1101 \\
$810-3$ & 95 & 0.4052 & 0.3989 & 0.0156 \\
$810-4$ & 95 & 0.2163 & 0.2137 & 0.0119 \\
$810-5$ & 95 & 0.4777 & 0.2137 & 0.0095 \\
\hline Mean & 95 & 0.2897 & 0.2731 & 0.0573 \\
St. Dev & & 0.0200 & 0.0172 & \\
\hline
\end{tabular}

$G s t=(H t-H s) / H t$, where,

$H t$ : total genetic diversity for the species,

$H s$ : mean heterozygosity within populations.

Table 5. - Analysis of Molecular Variance (AMOVA) for the four populations of A. senegal.

\begin{tabular}{lrrcccc}
\hline Source of variation & D.F. & SS & MS & $\begin{array}{c}\text { Variance } \\
\text { component }\end{array}$ & $\begin{array}{c}\text { \% Total } \\
\text { variation }\end{array}$ & $p$-value* \\
\hline Among populations & 3 & 20.132 & 6.711 & 0.153 & 5 & $<0.001$ \\
Within populations & 91 & 293.184 & 3.222 & 3.222 & 95 & $<0.001$ \\
Total & 94 & 313.316 & 9.933 & 3.375 & & \\
\hline
\end{tabular}

*After 999 random permutations.

Table 6. - ISSR Matrix of Nei's (1978) unbiased measures of genetic distance (D) for the four populations of A. senegal studied.

\begin{tabular}{lccc}
\hline & Bulla Sambul & Kutulo & Wamba \\
\hline Kutulo & 0.016 & & \\
Wamba & 0.034 & 0.028 & \\
Meisori & 0.016 & 0.028 & 0.009 \\
\hline
\end{tabular}

mean of 0.021 . The Meisori population was presented as being genetically closer to the Wamba population while the Kutulo population was closer to the Bulla Sambul population, although the genetic distance among the populations was so close. The relationships among individuals and populations as summarized by the PCoA (Peakall and Smouse, 2006), showed that about $40.75 \%$ of the total variation was described by the first two axes (Figure 2). This analysis indicated a lot of overlap among the populations to the extend that they could not be separated on the basis of geographic distances. For example, the Meisori population from the Baringo district overlaps extensively with the rest of the populations.

\section{Discussion}

The Nei's gene diversity index $(H)$ in this study ranged between 0.25 in the Wamba population to 0.30 in the Meisori population with a population mean of 0.27 . This was generally higher than that obtained in other acacias. In a similar study using RAPD markers, CASIVA et al. (2002) obtained $H$ values of 0.045 and 0.121 in Acacia aroma and Acacia macracantha respectively. Lower values of $\mathrm{H}$ were also obtained by CASIVA et al. (2004) using RAPD markers in Acacia caven $(H=0.141)$ and Acacia furcatispina $(H=0.045)$. The $H$ value obtained in this study was also higher than that obtained in other acacias using isozyme markers: A. auriculiformis $(H=0.146)$ and $A$. crassicarpa 


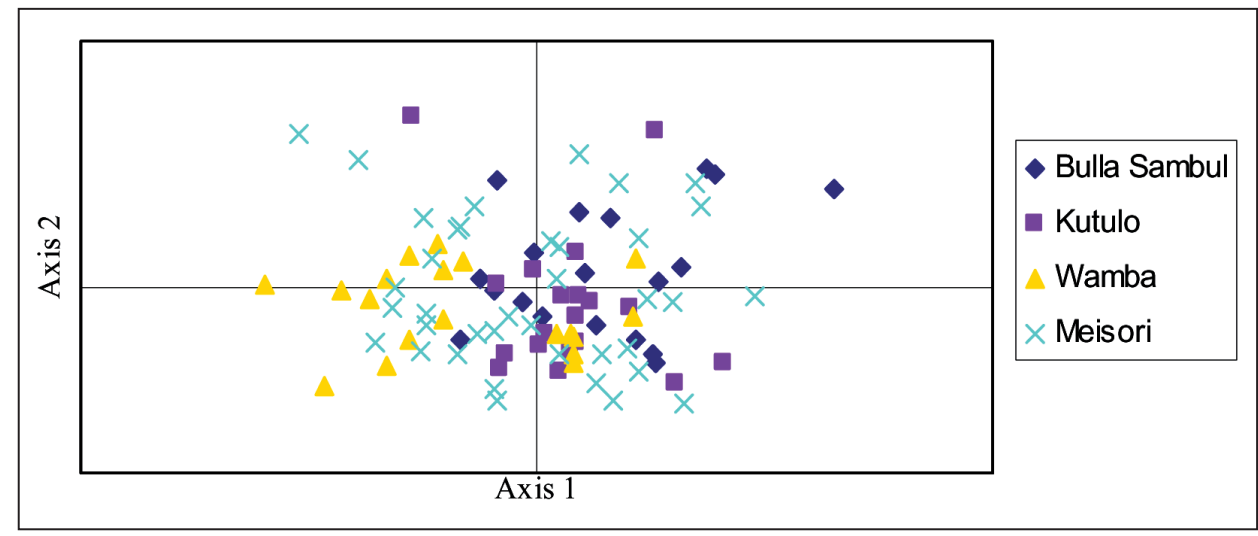

Figure 2. - Principle coordinate analysis of the 95 Acacia senegal individuals sampled. Axis 1 extracted $22.1 \%$ of the variance and axis 2 extracted $18.6 \%$ of the variance. Note that (a) The populations show overlap with other populations, and (b) Meisori from Baringo district is extensively spread and overlaps more with the rest of the populations.

$(H=0.141)$ (MorAn et al., 1989a); A anomala, $H=0.144$ (CoATEs, 1988) and Faidherbia albida, previously known as Acacia albida, $H=0.141$ (DANGASUK and GudU, 2000). For Argentinean species of Acacia, CASIVA et al. (2002) obtained estimates of $H$ ranging from 0.036 to 0.198 using isozymes. Similar to the range of our $H$ value, PLAYFORD et al. (1993) found high levels of genetic diversity $(H=0.208)$ in $A$. melanoxylon population in association with a great genetic differentiation among geographic areas, and MuONA et al. (1991) found low to high $H$ values in $A$. nilotica ranging from 0.167 to 0.458 , with a mean $H$ value of 0.293 using SSRs.

The percent polymorphic loci $(P)$ values obtained in this study $(87.4 \%)$ were by far higher than those observed in Acacia caven (29.4\%) (CASIVA et al., 2002), Acacia anomala (43\%) (COATES, 1988) and F. albida $(42.7 \%)$ (DANGASUK and GUDU, 2000). However, similar results were obtained in F. albida $(90 \%)$ reported by JoLY et al. (1992) using isozymes.

The average number of alleles per locus $(A)$ (1.86) was less than that reported for F. albida (2.5) (DANGASUK and GUDU, 2000), and 3.02 reported by JoLY et al. (1992) for F. albida. It was however higher than that reported by CAsIva et al. (2002) in A. aroma (1.2), A. macracantha (1.2) and A. caven (1.3).

The high level of genetic variation of $A$. senegal in this study based on the gene diversity index $(H)$ and percent polymorphic loci $(P)$ is consistent with its wide geographic range as was also the case with other acacias, since they occupy various habitats and encounter a variety of selection pressure. The most genetically variable population based on the mean number of alleles per locus $(A)$, percent of polymorphic loci $(P)$ and gene diversity index $(H)$ values was Meisori. This could be as a result of climatic influence. According to OLEGHE and AKINOUFESI (1992), the diversity of environmental conditions, especially moisture, under which A. senegal occurs naturally suggest that there is a great genetic variability among populations of the species. The Meisori population receives much rainfall (650 $\mathrm{mm}$ annually) as compared to the other three populations which receive $320 \mathrm{~mm}, 350 \mathrm{~mm}$ and $475 \mathrm{~mm}$ for Kutulo, Bulla Sambul and Wamba populations, respectively. BRAIN (1985,
1989), in a study of leaf peroxidase variation in South African populations of $A$. karroo, revealed interesting patterns of variation among them, suggesting the existence of distinct geographic races and the correlation of isozyme phenotypes with environmental factors such as low temperature and rainfall. Accordingly, DANGASUK et al. (2002) reported greatest genetic diversity in populations of Faidherbia albida located in areas of between $500 \mathrm{~mm}$ and $1000 \mathrm{~mm}$ annual rainfall. The genetic diversity increased with an increase in annual rainfall, with the peak genetic diversity being at $650 \mathrm{~mm}$, and this seems to apply to A. senegal as well. The Meisori population is also widespread and extensive and occurs in pure stand (MAUNDU et al., 1999), which supports the notion that tropical trees, especially those that are wide spread and occur at high densities maintain a high level of genetic diversity (Houston and Houston, 1993).

The Bulla Sambul and Kutulo populations have near similar environmental conditions and population densities which could be the possible reason for their near similar genetic diversity indices. Based on gene diversity index $(H)$, percent polymorphic loci $(P)$ and mean observed number of alleles $(A)$, the two populations could be said to be highly varied in comparison with the earlier mentioned studies. The Wamba population also occurs in a homogenous environment, though climatic conditions differ from those of Bulla Sambul and Kutulo, but the variation seems to fall within the same range. The A. senegal in Kenya naturally occurs in Arid and Semi Arid Lands (ASALs) comprising of the savannah grasslands. These environments normally experience intensive natural selection pressure to ensure survival and adaptation to the harsh environmental conditions of the Sahel region (ZoBel and TALBERT, 1984; BuRLEY et al., 1986) which might have led to the high genetic diversity. In addition, the animal form of seed dispersal, common in the Sahelian region (CORBASSON et al., 1985; HAMRICK and GODT, 1989), might have contributed to greater genetic diversity as a result of bringing together genetically different seed materials from various sources (FERNANDEZ et al., 1996).

Based on the Gst, most of the genetic variation in A. senegal resided within populations $(94.27 \%)$. Similar- 
ly, the AMOVA for the 95 samples showed high within population variation of $95 \%$. Therefore, A. senegal maintains a high level of genetic diversity within populations, as expected of an outcrossed, widespread species. Generally, acacias are highly diverse compared to other species including gymnosperms and conifers (McDonALD and MasLin, 2000). These results concur with those reported by OLNG'OTIE (1992) in A. tortilis subspecies heteracantha of which $24 \%$ of the variation existed among the populations while $76 \%$ resided within the populations, and in $A$. raddiana where $11 \%$ of the variation was found among the populations while $89 \%$ within the population. Similar results were also reported by CASIVA et al. (2004) in A. aroma and A. macracantha with $90.69 \%$ and $84.56 \%$ of the variation residing within the population, respectively and also by PLAYFORD et al. (1993) in populations of A. melanoxylon, for which $87.32 \%$ of the genetic diversity was found within populations.

The genetic distance (D) (NEI's, 1978) showed no clear cut differentiation of the populations of this species. The genetic distance ranged from 0.009 between the Meisori and the Wamba populations to 0.034 between the Wamba and the Bulla Sambul populations, with a population mean of 0.021. Such small genetic distances were also recorded by CASIVA et al. (2004) in A. macracantha (0.004) and A. aroma (0.048), also CASIVA et al. (2002) in A. caven (0.07) using RAPD markers. The genetic distance data was supported by the PCoA clustering of the individual trees in which there was a lot of overlap among the populations, with no clear cut geographic boundaries. For instance, the Meisori population spread extensively across the two axes, suggesting that it might be the centre of diversity for the Kenyan A. senegal populations.

According to HAMrICK and GoDT (1989) and MACDONALD et al. (2001), most genetic variation in plant species reside within populations, which is consistent with the results of this study. High levels of genetic variability, such as those observed in the present study, may be related to mating system and geographic distribution of the species. Species with outcrossed mating system and a wide geographic range have higher levels of genetic diversity than do selfer and endemic species. Likewise, species whose seeds are dispersed by animal ingestion or by wind maintain high levels of within-population genetic variability (HAMRICK and MURAWSKI, 1990; WACHIRA et al. 2001). Except for wind pollination, A. senegal exhibits all these traits and is thus expected to maintain a high level of genetic diversity both at the species and population levels.

The relevance of using dominant markers for assessing genetic diversity within and among individuals, within a considered area (usually much smaller than the species range), especially lies in providing ordination plots of individual genotype distances, clusters of (sub)populations on the basis of their averaged genetic distances, analysis of molecular variance within and between populations relative to the total, statistics and analogues tested by random permutation (TRIEST, 2008). In a recent review by TRIEST (2008), the sample size has an important influence on the interpretation of domi- nant markers especially when using small sample sizes, ranging from 4 to 20 per site, for conducting large-scale studies across oceans. For instance, ISSRs have often been used for the comparative study of genetic variability of mangrove populations across large geographical ranges. Despite the often low sample size of a population (10-20 individual mangrove trees), when pooled into regions, significant differences in genetic diversity estimates between regions were obtained. When the distribution area of a species is not fully covered, or with low sample size, and only distant populations across continents are compared, then the expected outcome with dominant markers is that, clearly divided clusters per geographic region will be obtained (TRIEST, 2008). Sampling precautions should therefore be taken in future, especially when carrying out a comprehensive comparative study on the genetic diversity of $A$. senegal across its entire distribution range in Africa. This will help avoid unnecessary geographical structuring of the populations which affects interpretation of the results.

The ISSR data was able to reveal the high level of genetic diversity within, and the lack of clear differentiation between Kenyan populations of $A$. senegal. The high within population genetic variation observed concurs with the species' outcrossed mating system, wide geographic range and animal mediated form of seed dispersal mechanism, as would be expected. The most variable population for all criteria was Meisori followed by Bulla Sambul, Kutulo and then Wamba. In conservation terms, the high level of within population genetic diversity is considered to be encouraging because genetic diversity and fitness are often considered to be positively correlated (REED and FRANKHAM, 2003). It can therefore be concluded that, rapid genetic gain could be attained through selection of individual trees within populations, which should also ensure a comprehensive coverage of the population's ecological amplitude.

\section{Acknowledgements}

The African Institute for Capacity Development (AICAD) financially supported this study. The Tea Research Foundation of Kenya (TRFK) permitted the use of its laboratory for the PCR/ISSR molecular work. Kenya Forestry Research Institute (KEFRI) was very instrumental during the sample collection. Kenya Forestry Service (KFS) through their District Forest Officers offered splendid support during the field work. International Centre for Research in Agroforestry (ICRAF) in Nairobi supported tremendously with data analysis.

\section{References}

ARCE, L. R and H. BANKS (2001): A preliminary survey of pollen and other morphological characters in neotropical Acacia subgenus Aculeiferum (Leguminosae: Mimosoideae). Botanical Journal of the Linnean Society 135: 263-270.

BARDAKCI, F. (2001): Random Amplified Polymorphic DNA (RAPD) Markers. Turkish Journal of Biololgy 25: 185-196.

Boen, E. (2002): Acacia senegal (L.) Willd. Record from Protabase. In: PROTA (Plant Resources of Tropical Africa), edited by L. P. A. Oyen and R. H. M. J. LeMMENS, Wageningen, the Netherlands. 
BrAIN, P. (1989): Genetic races in a ring species of Acacia karroo. South African Journal of Science 85: 81-85.

BRAIN, P. (1985): Leaf peroxidase types in Acacia karroo. Geographical distribution and influence of the environment. South African Journal of Botany 52: 47-52.

BrenAN, J. P. M. (1983): Manual on taxonomy of Acacia species. Rome FAO Forestry Division.

Burley, J., C. E. Hughes and B. T. Styles (1986): Genetic systems of tree species for arid and semiarid lands. Forestry Ecology and Management 16: 317-344.

CAMACHO, F. J. and A. Liston (2001): Population structure and genetic diversity of Botrychium pumicola (Ophioglossaceae) based on inter-simple sequence repeats (ISSR). American Journal of Botany 88: 1065-1070.

Casiva, P. V., B. O. Saidman, J. C. Vilardi and A. M. Cialdellan (2002): First comparative phenetic studies of Argentinean species of Acacia (Fabaceae), using morphometric, isozymal, and RAPD approaches. American Journal of Botany 89: 843-853.

Casiva, P. V., J. C. Vilardi, A. M. Cialdellan and B. O. SAIDMAN (2004): Mating system and population structure of Acacia aroma and A. macracantha (Fabaceae). American Journal of Botany 91(1): 58-64.

Chikamai, B. N. and J. A. Odera (2002) Commercial plants gums and resins in Kenya. Nairobi, Kenya. 47-52.

COATES, D. J. (1988): Genetic diversity and population genetic structure in the rare Chittering grass wattle Acacia anomala. Australian Journal of Botany 36: 273-286.

Corbasson, M., Y. Roedere and E. Forni (1985): Acacia albida (Del.). Characteristics and ecology of the species, exploration of genetic resources and collection of provenances for international trials. Forestry Genetics Resources Information No. 15, FAO, Rome, Italy.

Cossalter, C. (1991): Acacia senegal; gum trees with promise for Agroforesrty. NFT Highlights No. 91-02.

DANGasuk, O. G. and S. Gudu (2000): Allozyme variation in 16 natural populations of Faidherbia albida (Del.) A. Chev. Hereditas 133: 133-145.

Dangasuk, O. G., S. Gudu, R. A. Aman and R. Brandl (2002): Isozyme variation and growth performance in 16 provenances of African Faidherbia albida (Del.) A. Chev. in Kenya. Discovery and Innovation special edition 26-36.

Dondain, G. and G. O. Phillips (1999): The regulatory journey of gum arabic. Foods and Food Ingredients Journal 179: 38-56.

Esselman, E. J., D. Crawford, S. Brauner, I. F. Stussy, G. J. ANDERSON and M. O. Silva (2000): RAPD marker diversity within and divergence among species of Dendroseris (Asteraceae: Lactuceae). American Journal of Botany 87: 591-596.

Esselman, E. J., L. Jianqiamg, D. J. CraWford, J. L. WinDUS and A. D. WeLFE (1999): Clonal diversity in the rare Calamagrostis porteri spp. insperata (Poaceae): comparative results for allozymes and random amplified polymorphic DNA and inter-simple sequence repeat markers. Molecular Ecology 8: 443-453.

FAGG, C. W. and G. E. Allison (2004): Acacia senegal and gum arabic trade. Oxford Forestry Institute. Tropical Forestry papers No. 42.

FAO and UNEP (1983): Notes on trees and shrubs in arid and semi arid regions. EMASAR phase 11. FAO, Rome, Italy.
FAO/IAEA (2002): Mutant Germplasm Characterization using molecular markers. A manual prepared by the Joint FAO/IAEA Division of Nuclear Techniques in Food and Agriculture. International Atomic Energy Agency (IAEA), Vienna.

Fernandez, A., R. E. Schutzki and J. F. HAncock (1996): Isozyme and morphological variation in a Cornus flori$d a$ L. Provenance plantation and representing geographically diverse populations. Journal of American Society and Horticultural Science 121(2): 225-230.

HAMRICK, J. L and M. J. W. GODT (1989): Allozyme diversity in plant species, pp. 1-19. In: Plant Population Genetics, Breeding and Genetic Resources, edited by A. H. D. Brown, M. T. Cleyg, A. L. Kahler and B. S. WeIR, Sinaner, Massachussetts.

Hamrick, J. L. and D. MuraWsKi (1990): The breeding structure of tropical tree populations. Plant species biology 5: 157-167.

Hantula, J., M. Dusabenygasani and R. C. Hamelin (1996): Random amplified microsatellites (RAMS) - a novel method for characterizing genetic variation within fungi: European Journal of Forestry Pathology 26: $15-166$.

Houston, D. B. and D. R. Houston (1993): Variation in American beech (Fagus grandifolia Ehrh): Isozyme Analysis of Genetic Structure in Selected Stands. Silvae Genetica 43(5/6): 227-284.

Internationale Centre for Research in Agroforestry (1992): A selection of useful trees and shrubs of Kenya. Kenya, ICRAF.

Joly, H. I., M. Zeh-Nio, P. Danthu and C. Aygalent (1992): Population genetics of an African acacia: Acacia albida. Genetic diversity of populations from West Africa. Australian Journal of Botany 40: 59-73.

MacDonald, S. E., B. R. Thomas, D. M. Cheniawsky and B. G. PURDY (2001): Managing genetic resources of iodgepole pine in West-Central Alberta: Patterns of isozyme variation in natural populations and effects of forest management. Forest Ecology Management 152: $45-58$.

Manniatis, T., E. F. Fritsch and J. SAMBrook (1982): Molecular cloning: A laboratory manual-cold spring harbor. Cold Spring Hobart Publications.

Maundu, P. M., G. W. NGugi and H. C. Kasuye (1999): Traditional food plants of Kenya. Nairobi, Kenya.

McDonald, M. W. and B. R. MAslin (2000): Taxonomic revision of the salwoods: Acacia aulacocarpa Cunn. Ex. Benth; and its allies (Leguminosae: Mimosoideae: section juliflorae). Australian Systematic Botany 13: $21-78$.

Mondal, T. K. (2002): Assessment of genetic diversity of tea (Camellia sinensis (L.). O. Kuntze) by inter-simple sequence repeat polymerase chain reaction. Euphytica 128: 307-315.

Moran, G. F., O. Mouna and J. C. Bell (1989a): Acacia mangium: A tropical forest tree of the coastal lowlands with low levels of genetic diversity. Evolution 43: 231-235.

Muona, O., G. F. Moran and J. C. Bell (1991): Hierarchical patterns of correlated mating in Acacia melanoxylon. Genetics 127: 619-626.

Nan, P., S. Shi, S. Peng, C. Tian and Y. Zhong (2003): Genetic diversity in Primular obconica (Primulaceae) from central and south-west China as revealed by ISSR markers. American Journal of Botany 91: 329-333.

National ACADEmy of Sciences (1984): Tropical legumes: Resources for the future. Washington DC. 
NEI, M. (1973): Analysis of gene diversity in subdivided populations. Genetics 70: 3321-3323.

NEI, M. (1978): Estimation of average heterozygosity and genetic distance from a small number of individuals. Genetics 89: 583-590.

Oleghe, P. E. and F. K. Akinoufesi (1992): Gum yield of Acacia senegal as affected by soil and water potential and season of tapping. Nitrogen fixing Tree Research reports 10: 106-109.

OlnG'OTIE, P. A. S. (1992): Acacia tortilis (Forsk.) Hayne: A study of Genetic Diversity and Breeding Systems. Unpubl. D. Phil. Thesis. Oxford University, Oxford, England, pp. 117.

Peakall, R and P. E. SMouse (2006): GENALEX 6: genetic analysis in Excel. Population genetic software for teaching and research. Molecular Ecology Notes 6: 288-295.

Playford, J., J. C. Bell and G. F. Moran (1993): A major disjunction in genetic diversity over the geographic range of Acacia melanoxylon $\mathrm{R}$. Br. Australian Journal of Botany 41: 355-368.

REeD, D. H. and R. Frankham (2001): How closely correlated are molecular and Quantitative measures of genetic variation? A mata-analysis. Evolution 55: 1095-1103.

TRIEST, L. (2008): Molecular ecology and biogeography of mangrove trees towards conceptual insights on gene flow and barriers: A review. Aquatic Botany 89: 138-154.
WAChiRA, F. N., J. TANAKA and Y. TAKEDA (2001): Genetic variation and differentiation in tea (Camellia sinensis) germplasm revealed by RAPD and AFLP variation. Journal of Horticultural Science and Biotechnology 76(5): 557-563.

Williams, J. G. K., A. R. Kubelik, K. J. LivaK, J. A. RAFALSKI and S. V. TINGEY (1990): DNA polymorphisms amplified by arbitrary primers are useful as genetic markers. Nucleic Acids Research 18: 6531-6535.

Wolfe, A. D. and A. Liston (1998): Contributions of PCRbased methods to plant systematics and evolutionary biology, pp. 43-86. In: Molecular systematics of plants: DNA sequencing, edited by P. S. Soltis, D. E. Soltis and J. J. DOYLE, Kluwer, New York.

Yeh, F. C., R. C. YANG, T. B. J. Boyle, Z. H. Ye and J. X. MAO (1999): POPGENE 3.2, the User Friendly Shareware for Population Genetic Analysis. Molecular Biology and Biotechnology Center, University of Alberta, Edmonton.

Zietkiewicz, E., A. RAFAlKI and D. LABUdA (1994): Genome fingerprinting by Simple Sequence Repeat (SSR)-anchored polymerase chain reaction amplification. Genomics 20: 176-183.

Zobel, B. and J. TALBERT (1984): Applied Forest Tree Improvement. John Wiley and Sons, New York.

\title{
A New Breeding Strategy for Pinus radiata in New Zealand and New South Wales
}

\author{
By H. S. DungeY ${ }^{1), *}$, J. T. Brawner ${ }^{2), 3)}$, F. Burger ${ }^{4)}$, M. Carson ${ }^{5)}$, M. Henson ${ }^{6)}$, P. Jefferson ${ }^{7)}$ and A. C. Matheson ${ }^{8)}$
}

(Received $13^{\text {th }}$ November 2007)

\begin{abstract}
A new breeding strategy is presented for the Radiata Pine Breeding Company, a New Zealand based research consortium, that drives the breeding program for Pinus radiata for both the New Zealand and New South Wales

1) Scion, Private Bag 3020, Rotorua, New Zealand.

2) Horizon2, 1943 State Highway 30, Te Teko, RD 2 Whakatane, New Zealand.

3) Present address: CSIRO Plant Industry, 11 Garnet Street, PO Box 873, Cooroy, Queensland 4563, Australia.

4) Carter Holt Harvey Forests Ltd, Ngahere house, Vaughans Road Rotorua.

5) Forest Genetics, 34 Parawai Rd, Rotorua, New Zealand.

$\left.{ }^{6}\right)$ Forests NSW, PO Box 100 Beecroft NSW, 2119, Australia.

$\left.{ }^{7}\right)$ Radiata Pine Breeding Company, 430 Ngongotaha Road, Ngongotaha, Rotorua, New Zealand.

8) CSIRO Plant Industry, PO Box E4008 Kingston, Canberra, 2604, ACT, Australia.

*) Communicating author: HeIDI S. Dungey. Ph +64-7-3435629,

Fax +64-7-348 0952. E-Mail: heidi.dungey@scionresearch.com
\end{abstract}

based Australian forest plantation industry. The new strategy builds on the existing base for $P$. radiata, and on the last strategy review in 2000.

The new strategy comprises a large open-pollinated (OP) Main Population (MP) with 500 female parents and two sublines (250 female parents per subline). The MP will be tested using alpha designs, single-tree plots and incomplete blocks to maximise efficiency. Each subline will be tested on four sites, geographically distant from the other subline. The MP will be managed in discrete generations. Selection of the next generation will be using a combination of backward and forward selection, but the strict control of inbreeding with identified lineage will rely on the development of parental reconstruction for OP progeny. There are alternatives to this, however, such as estimating the group coancestry and accepting some additional increase in inbreeding. This is a new and significant departure from previous breeding strategies for $P$. radiata in New Zealand.

There will also be a single, small Elite Population (EP), tested $50 \%$ as progeny and $50 \%$ as clones. Twenty 